\title{
Marmoricola aurantiacus gen. nov., sp. nov., a coccoid member of the family Nocardioidaceae isolated from a marble statue
}

\author{
Clara Urzì, ${ }^{1}$ Paola Salamone, ${ }^{1}$ Peter Schumann ${ }^{2}$ and Erko Stackebrandt ${ }^{2}$
}

Author for correspondence: Clara Urzì. Tel: +39090 6765196. Fax: +39090 392733.

e-mail: urzicl@unime.it

1 Institute of Microbiology, Faculty of Science, University of Messina, Salita Sperone 31, I-98166 Villagio S. Agata Messina, Italy

2 DSMZ-German Collection of Microorganisms and Cell Cultures $\mathrm{GmbH}_{\text {, }}$ Mascheroder Weg $1 \mathrm{~b}$, D-38124 Braunschweig, Germany

\begin{abstract}
A Gram-positive, aerobic bacterium with coccoid cells occurring singly, in pairs and in clusters was isolated from the surface of a marble statue. The peptidoglycan contains LL-diaminopimelic acid as diagnostic diamino acid and a single glycine residue as interpeptide bridge (type $\mathbf{A} 3 \gamma$ ). The major menaquinone is $\mathrm{MK}-\mathbf{8}\left(\mathrm{H}_{4}\right)$. The cellular fatty acid pattern consists of straight chain saturated and monounsaturated components and 10-methyl octadecanoic (tuberculostearic) acid as the only branched chain fatty acid. Phosphatidylinositol, phosphatidylglycerol and diphosphatidylglycerol occur as characteristic polar lipids. The DNA G+C composition is $72 \mathrm{~mol} \%$. According to its phylogenetic position and 16S rDNA signature nucleotides, the organism is a member of the family Nocardioidaceae. The combination of chemotaxonomic characteristics is unique within this family and supports the description of a new genus and new species, Marmoricola aurantiacus. The type strain is strain BC $361^{\top}$ ( = DSM $12652^{\top}$ ).
\end{abstract}

Keywords: Marmoricola aurantiacus, marble, Nocardioidaceae, chemotaxonomy, phenotypic characteristics

\section{INTRODUCTION}

Actinobacteria with LL-diaminopimelic acid (LL$\mathrm{A}_{2} \mathrm{pm}$ ) cluster into five families belonging to four suborders on the basis of characteristic signature nucleotides of $16 \mathrm{~S}$ rDNA: (i) Nocardioidaceae (suborder Propionibacterineae), (ii) Propionibacteriaceae (suborder Propionibacterineae), (iii) Intrasporangiaceae (suborder Micrococcineae), (iv) Sporychthiacea (suborder Frankineae) and (v) Streptomycetaceae (suborder Streptomycineae) (Stackebrandt et al., 1997). The genera of these families can readily be distinguished by their chemotaxonomic characteristics (Schumann et al., 1997; Prauser et al., 1997; Busse \& Schumann, 1999). The family Nocardioidaceae (Stackebrandt et al., 1997) comprises the genera Nocardioides and Aeromicrobium which differ in their major isoprenoid quinone, cellular fatty acid profile and polar lipid pattern.

The genus Nocardioides includes at present six species,

Abbreviations: LL- $\mathrm{A}_{2} \mathrm{pm}$, LL-diaminopimelic acid; TBSA, 10-methyl octadecanoic acid (tuberculostearic acid).

The GenBank/EMBL/DDBJ accession number for the 165 rDNA sequence of strain $B C 361^{\top}$ is $Y 18629$. namely Nocardioides albus (Prauser, 1976), Nocardioides simplex (O'Donnell et al., 1982), Nocardioides jensenii (Suzuki \& Komagata, 1983; Collins et al., 1989), Nocardioides luteus (Prauser, 1984), Nocardioides plantarum (Collins et al., 1994) and Nocardioides pyridinolyticus (Yoon et al., 1997). Nocardioides fastidiosa proposed by Collins \& Stackebrandt (1989) has been transferred to the genus Aeromicrobium as Aeromicrobium fastidiosum by Tamura \& Yokota (1994) on the basis of chemotaxonomic and phylogenetic data. Though Nocardioides species are heterogeneous with respect to morphology, embracing strains that form mycelium which may fragment into irregular rod- and coccuslike cells as well as true rods and cocci, they are coherent in chemotaxonomic properties. The peptidoglycan of all representatives of the genus Nocardioides contains LL- $\mathrm{A}_{2} \mathrm{pm}$ and is of the $\mathrm{A} 3 \gamma$ type (Schleifer \& Kandler, 1972) with a single glycine residue as interpeptide bridge. The genus lacks mycolic acids and has a tetrahydrogenated menaquinone with eight isoprene units [MK-8 $\left.\left(\mathrm{H}_{4}\right)\right]$ as predominant isoprenoid quinone (O'Donnell et al., 1982). Nocardioides strains show complex cellular fatty acids including isoand anteiso-branched, straight-chain saturated and unsaturated components and 10-methyl octadecanoic 
acid (tuberculostearic acid; TBSA). The predominance of iso- $\mathrm{C}_{16: 0}$ is characteristic for the genus (Yoon et al., 1997; Park et al., 1998). The polar lipid profiles include phosphatidylglycerol, diphosphatidylglycerol and two $\alpha$-glycol positive phospholipids (O'Donnell et al., 1982).

The genus Aeromicrobium embraces the two species Aeromicrobium erythreum and A. fastidiosum. Representatives of the genus Aeromicrobium form rod-like or coccoid cells. Members of this genus display the same peptidoglycan type A3 $\gamma$ as Nocardioides species but differ from them in that they contain the tetrahydrogenated menaquinone with nine isoprenoid units MK-9 $\left(\mathrm{H}_{4}\right)$, exclusively straight-chain saturated and monounsaturated fatty acids and phosphatidylethanolamine (Miller et al., 1991; Tamura \& Yokota, 1994).

This paper describes the morphological, physiological and chemotaxonomic characterization of a coccoid LL$\mathrm{A}_{2} \mathrm{pm}$ containing strain isolated from a marble statue of the Nordfriedhof cemetery in Munich (Germany) and the determination of its phylogenetic position on the basis of its $16 \mathrm{~S}$ rDNA sequence. Because of the unique combination of its characteristics among members of the family Nocardioidaceae, a new genus and species, Marmoricola aurantiacus, is proposed.

\section{METHODS}

Bacterial strain. Strain BC $361^{\mathrm{T}}$ was isolated from a marble statue (Wagmüller's monument), in the old Nordfriedhof cemetery in Munich, Germany. The organism was isolated by dilution plating on Bunt and Rovira medium (Bunt \& Rovira, 1955), modified by addition of $0.5 \%$ glucose, $0.5 \%$ $\mathrm{NaCl}$ and $0.03 \% \mathrm{Na}_{2} \mathrm{CO}_{3}, \mathrm{pH} 8.6$ (BRII). For morphological and chemotaxonomic studies, strain BC 361 ${ }^{\mathrm{T}}$ was cultivated in Luedemann medium (Luedemann, 1968).

Staining procedures. Gram staining and acid-fast staining were done as described previously (Lanyi, 1987) and Luedemann staining was performed as described by Luedemann (1968).

Morphological characteristics. Cell and aggregate morphology were determined by bright-field microscopy and by phase-contrast microscopy (DML, Leica; oil immersion objective, magnification $\times 100$ ) and scanning electron microscopy (SEM) (Leo Electron Microscopy), from material obtained from surface growth on agar plates.

For SEM observations, a $14 \mathrm{~d}$ old strain $\mathrm{BC} 361^{\mathrm{T}}$ culture from Luedemann medium was suspended in PBS $(0.13 \mathrm{M}$ $\mathrm{NaCl}$ in $0 \cdot 1 \mathrm{M} \mathrm{KH}_{2} \mathrm{PO}_{4} / \mathrm{NaOH}$ buffer, $\left.\mathrm{pH} 7 \cdot 4\right)$. The cells

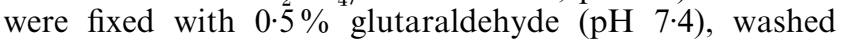
several times and dehydrated in a series of ethanol concentrations. After the cells were sputter-coated with goldpalladium, they were observed under a scanning electron microscope (Groth et al., 1997).

Physiological and biochemical characterization. All physiological tests were performed at $28^{\circ} \mathrm{C}$. Oxidase activity was determined by monitoring the oxidation of $N, N, N^{\prime}, N^{\prime}$ tetramethyl- $p$-phenylenediamine on filter paper. Acidification of carbohydrates was verified by a colour change from blue to yellow in a medium containing $0.5 \%$ tryptone
(Oxoid), 0.4\% bacto casamino acids (Difco), 0.07\% $\left(\mathrm{NH}_{4}\right)_{2} \mathrm{HPO}_{4}, 0.5 \% \mathrm{NaCl}, 0.003 \%$ bromocresol purple, and the substrates at a final concentration of $1 \%$ (Schumann et al., 1997). Catalase production was shown by the production of bubbles after a suspension of the cells was mixed with a drop of a $3 \%$ hydrogen peroxide solution on a slide. DNA hydrolysis was indicated by clear zones in spot-inoculated plates containing DNase agar (Oxoid). The hydrolysis of casein and the decomposition of tyrosine, xanthine and hypoxanthine were determined as described previously (Gordon et al., 1974).

Urease activity, nitrate reduction, aesculin hydrolysis, hydrolysis of starch, hydrolysis of Tween $(20,40,60,80)$, phosphatase production and hydrolysis of gelatin were studied by using previously described methods (Lanyi, 1987). Strain BC $361^{\mathrm{T}}$ was examined for its ability to grow in Czapek Dox modified agar (CZ; Oxoid), potato dextrose agar (PDA; Oxoid), brain-heart infusion agar (BHIA; Oxoid), $1.5 \%$ agar- $\mathrm{H}_{2} \mathrm{O}$, YMS-Glc agar $(0.5 \%$ yeast extract, $1.5 \%$ malt extract, $1 \%$ starch, $1 \%$ glucose, $1.5 \%$ agar), YCS-Glc agar $(0.5 \%$ yeast extract, $1.5 \%$ casein hydrolysate, $1 \%$ starch, $1 \%$ glucose, $1.5 \%$ agar $)$, Y-Glyc agar $(0.5 \%$ yeast extract, $2 \%$ glycerol, $1.5 \%$ agar), YG-Glyc agar ( $0.5 \%$ yeast extract, $1 \%$ glucose, $10 \%$ glycerol, $1.5 \%$ agar $)$ (Luedemann \& Fonseca, 1989) and in medium M53 Corynebacterium agar (Collins \& Stackebrandt, 1989).

Cell wall analysis. Purified cell wall preparations were obtained by the method of Schleifer (1985). The amino acids and peptides in cell wall hydrolysates were analysed by twodimensional ascending TLC on cellulose plates using the described solvent systems (Schleifer, 1985). Whole-cell sugars were determined as alditol acetates by GC as described (Groth et al., 1996). The molar ratios of amino acids were determined by GC and GC-MS of $N$-heptafluorobutyryl amino acid isobutyl esters (MacKenzie, 1987). The glycolate content of bacterial cell walls was determined by the colorimetric method of Uchida \& Aida (1984).

Lipid analysis. Cellular fatty acid methyl esters obtained from cells grown in bacto tryptic soy broth at $28{ }^{\circ} \mathrm{C}$ by the method described by Stead et al. (1992) were separated by GC (Groth et al., 1996) and identified as described previously (Schumann et al., 1997). Menaquinones were extracted as described by Collins et al. (1977) and were analysed by HPLC (Groth et al., 1996). Polar lipids extracted by the method of Minnikin et al. (1979) were identified by twodimensional TLC and spraying with specific reagents (Collins \& Jones, 1980). The absence of mycolic acids was demonstrated by TLC (Minnikin et al., 1975).

DNA base composition. DNA was isolated and its $\mathrm{G}+\mathrm{C}$ content was determined by HPLC of deoxyribonucleosides as described previously (Groth et al., 1996).

$16 \mathrm{~S}$ rDNA sequence determination and analysis. Extracted genomic DNA was used for PCR-mediated amplification of 16S rDNA (Rainey et al., 1996). The purified PCR product was directly sequenced by using previously described protocols (Rainey et al., 1996), and the sequence reaction mixtures were electrophoresed with a model 373A automatic DNA sequencer.

The 16S rDNA sequences were manually aligned with the sequences of members of the order Actinomycetales by using the ae 2 editor (Maidak et al., 1994). Evolutionary distances for strain $\mathrm{BC} 361^{\mathrm{T}}$ and for a selection of actinobacterial strains (data not shown) were calculated by a previously described method (Jukes \& Cantor, 1969). Phylogenetic 


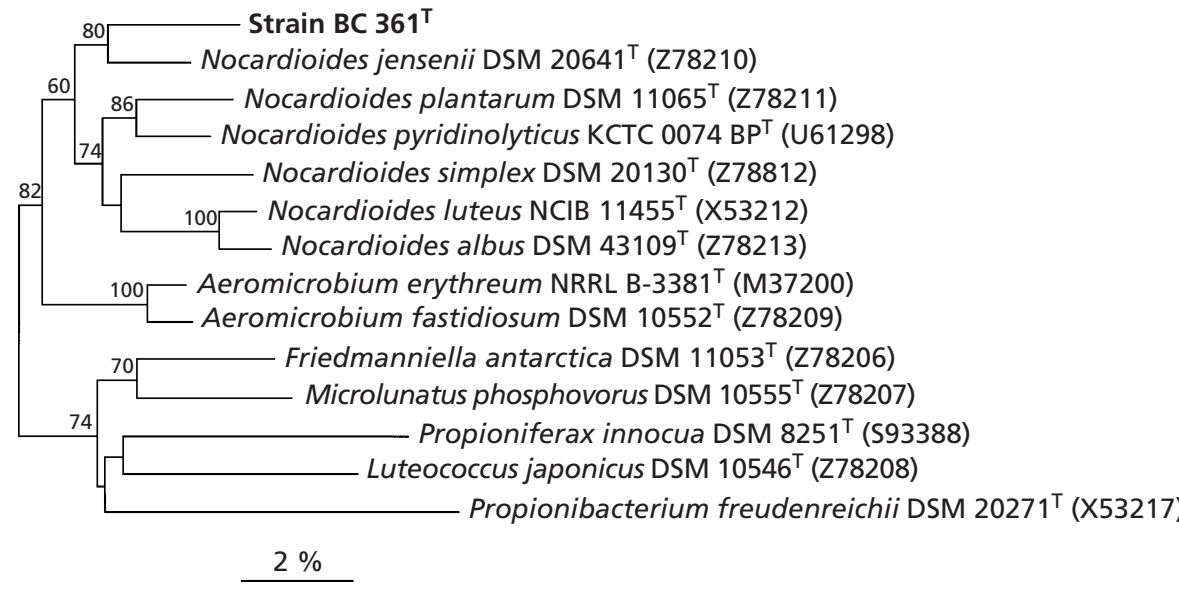

Fig. 1. Phylogenetic dendrogram based on the results of a 165 rDNA sequence comparison. Bar, 2 nucleotide substitutions per 100 nucleotides.

dendrograms were reconstructed by using the treeing algorithm of DeSoete (1983) and the neighbour-joining algorithm contained in the PHYLIP package (Felsenstein, 1993). Bootstrap analyses were used to evaluate the tree topologies of the neighbour-joining data by performing 500 resamplings (Felsenstein, 1993). Strain numbers and rDNA accession numbers of reference organisms are included in Fig. 1.

\section{RESULTS}

\section{Cultural and morphological characteristics}

Growth occurred after 2 weeks in Luedemann medium at $28{ }^{\circ} \mathrm{C}$. The colonies were circular (diameter 2-5 $\mathrm{mm}$ ), with a smooth surface, shiny and orange coloured (Fig. 2). In old cultures (2-3 months incubation), colonies had the tendency to become shaped like craters and were sometimes rough. Cells were spherical $(0 \cdot 5-0.7 \mu \mathrm{m}$ in diameter) and occurred singly,



Fig. 2. Single $B C 361^{\top}$ colony (after $30 \mathrm{~d}$ incubation on Luedemann medium); diameter $4.5 \mathrm{~mm}$. Bar, $1 \mathrm{~mm}$. in pairs or in tetrads (Fig. 3) and in some cases in clusters (old cultures). The temperature range for growth on Luedemann medium was $18-28^{\circ} \mathrm{C}$, no growth occurred at 6 and $37^{\circ} \mathrm{C}$. Growth occurred within a range of $\mathrm{pH}$ between $5 \cdot 1$ and $8 \cdot 7$. Addition of $2 \% \mathrm{NaCl}$ to Luedemann medium resulted in a restricted growth, whereas no growth occurred in the presence of $4 \% \mathrm{NaCl}$.

\section{Physiological characteristics}

The physiological and biochemical characteristics of strain BC $361^{\mathrm{T}}$ are summarized in Table 1. Strain BC $361^{\mathrm{T}}$ was negative for oxidase and urease tests. Catalase was produced. Nitrate was not reduced to nitrite. No acid was produced from D-ribose, L-arabinose, D-xylose, L-rhamnose, D-glucose, Dmannose, D-galactose, maltose, lactose, D-cellobiose, D-trehalose, D-raffinose, glycerol, D-mannitol and myoinositol. Casein and gelatin were not hydrolysed. Xanthine and tyrosine were not decomposed, whereas hypoxanthine was decomposed. Aesculin was hydrolysed, Tween 20, 40, 60 were not hydrolysed, whereas Tween 80 was only weakly hydrolysed. DNA was not hydrolysed. The strain did not grow in the following media: CZ, YMS-Glc, YCS-Glc, YG-Glyc, $\mathrm{Y}-\mathrm{Glyc}$, agar- $\mathrm{H}_{2} \mathrm{O}$ and $\mathrm{M} 53$. Growth occurred in PDA and BHIA medium.

\section{Chemotaxonomic characteristics}

The peptidoglycan of strain BC $361^{\mathrm{T}}$ contained LL$\mathrm{A}_{2}$ pm, Ala, Gly and Glu in a molar ratio of $1 \cdot 0: 1 \cdot 0: 0 \cdot 9: 0 \cdot 7$. From these results and from the twodimensional TLC peptide pattern of partial cell-wall hydrolysates (data not shown), it was concluded that strain $\mathrm{BC} 361^{\mathrm{T}}$ represented peptidoglycan type $\mathrm{A} 3 \gamma$ with a single glycine residue as an interpeptide bridge (Schleifer \& Kandler, 1972). Glucose and traces of ribose could be detected only as whole-cell sugars. The acyl type was acetyl. The fatty acid profile of strain BC $361^{\mathrm{T}}$ was characterized by the predominance of hexadecanoic acid $\left(\mathrm{C}_{16: 0}\right)$ and octadecenoic acid $\left(\mathrm{C}_{18: 1}\right)$, and by the presence of $\mathrm{C}_{16: 1}, \mathrm{C}_{14: 0}, \mathrm{C}_{18: 0}$ and TBSA as 


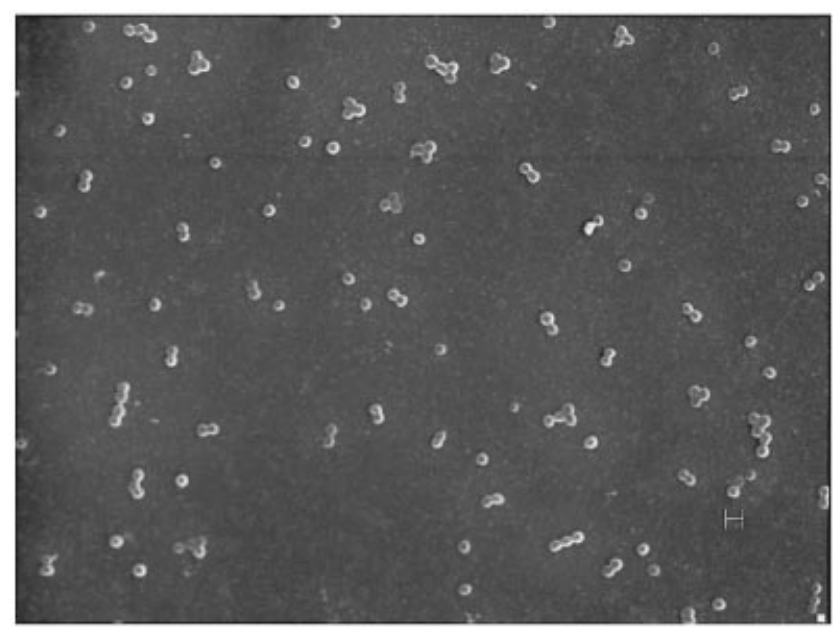

Fig. 3. Scanning electron micrograph of coccoid cells from $14 \mathrm{~d}$ old culture of strain $\mathrm{BC} 361^{\top}$ grown at $28{ }^{\circ} \mathrm{C}$ on Luedemann medium. Bar, $1 \mu \mathrm{m}$.

minor components (Table 2). The isoprenoid quinones were MK-8( $\left.\mathrm{H}_{4}\right)$, MK-7( $\left.\mathrm{H}_{4}\right)$, MK-8( $\left.\mathrm{H}_{2}\right)$, MK-6( $\left.\mathrm{H}_{4}\right)$; the peak area ratio was $73: 4: 1: 1$. The polar lipid pattern consisted of phosphatidylinositol, phosphatidylglycerol, diphosphatidylglycerol and one unknown phospholipid. Mycolic acids were absent. The DNA $\mathrm{G}+\mathrm{C}$ composition was $72 \mathrm{~mol} \%$ (Table 3 ).

\section{$16 S$ rDNA sequence analysis}

The almost complete $16 \mathrm{~S}$ rDNA sequence of $1470 \mathrm{nt}$ (95.5\% of the Escherichia coli sequence) was determined for strain $\mathrm{BC} 361^{\mathrm{T}}$ and compared to the sequences of the 16S rDNA database of members of the class Actinobacteria (Stackebrandt et al., 1997). The highest similarity values were found with representatives of the family Nocardioidaceae (>93\%), whereas they were slightly lower with members of the neighbouring families, i.e. Microlunatus, Propioniferax, Luteococcus, Friedmanniella and Propionibacterium (similarity between $89 \cdot 6$ and $92 \cdot 6 \%$ ).

Strain BC $361^{\mathrm{T}}$ shares the highest binary $16 \mathrm{~S}$ rDNA similarity with the type strain $N$. jensenii $(96.4 \%)$. The two treeing algorithms place these two organisms as a sister lineage to the lineage containing the other species of Nocardioides [Fig. 1 showing the phylogenetic tree according to the algorithm of DeSoete (1983)], whereas the Aeromicrobium line of descent branches slightly deeper. The inclusion of the $16 \mathrm{~S}$ rDNA sequence into the database does not change the branching point of $N$. jensenii which has been demonstrated in previous phylogenetic studies to represent the deepest point within the genus Nocardioides (Tamura \& Yokota, 1994; Schumann et al., 1997; Yoon et al., 1998a).

Although strain BC $361^{\mathrm{T}}$ clusters within the radiation of Nocardioides species and shares with them the
Table 1. Morphological and biochemical characteristics of strain $\mathrm{BC} 361^{\top}$

-, Negative; + , positive; w, weakly positive.

\begin{tabular}{|c|c|}
\hline Characteristic & Strain BC $361^{\mathrm{T}}$ \\
\hline Colour of colony & Orange \\
\hline Cell morphology & $\begin{array}{c}\text { Coccus, } 0 \cdot 5-0.6 \mu \mathrm{m} \text {, } \\
\text { packet, clusters }\end{array}$ \\
\hline Gram staining & + \\
\hline Acid-fast staining & - \\
\hline Spore formation & - \\
\hline $\mathrm{KOH}$ & - \\
\hline Catalase & + \\
\hline Oxidase & - \\
\hline Growth in: & - \\
\hline $\mathrm{CZ}$ & - \\
\hline PDA & + \\
\hline BHIA & + \\
\hline YMS-Glc & - \\
\hline YCS-Glc & - \\
\hline YG-Glyc & - \\
\hline Y-Glyc & - \\
\hline Agar- $\mathrm{H}_{2} \mathrm{O}$ & - \\
\hline M53 & - \\
\hline \multicolumn{2}{|l|}{ Growth at: } \\
\hline $6^{\circ} \mathrm{C}$ & - \\
\hline $18^{\circ} \mathrm{C}$ & + \\
\hline $22{ }^{\circ} \mathrm{C}$ & + \\
\hline $25^{\circ} \mathrm{C}$ & + \\
\hline $28^{\circ} \mathrm{C}$ & + \\
\hline $37^{\circ} \mathrm{C}$ & - \\
\hline \multicolumn{2}{|l|}{ Growth at $\mathrm{pH}$ : } \\
\hline $5 \cdot 1$ & + \\
\hline 6 & + \\
\hline $7 \cdot 2$ & + \\
\hline $8 \cdot 7$ & + \\
\hline \multicolumn{2}{|c|}{ Growth in the presence of $\mathrm{NaCl}$ : } \\
\hline $0 \cdot 5 \%$ & + \\
\hline $2 \%$ & + \\
\hline $4 \%$ & - \\
\hline $6 \%$ & - \\
\hline $10 \%$ & - \\
\hline Phosphatase & - \\
\hline Nitrate reduction & - \\
\hline \multicolumn{2}{|l|}{ Degradation tests: } \\
\hline Aesculin & + \\
\hline Urea & - \\
\hline Xanthine & - \\
\hline Casein & - \\
\hline Hypoxanthine & + \\
\hline Gelatin & - \\
\hline Starch & - \\
\hline Tween 20 & - \\
\hline Tween 40 & - \\
\hline Tween 60 & - \\
\hline Tween 80 & $\mathrm{w}$ \\
\hline Tyrosine & - \\
\hline DNA & - \\
\hline
\end{tabular}


Table 2. Cellular fatty acid composition of strain $\mathrm{BC} 361^{\top}$ and of type strains of Aeromicrobium and Nocardioides species

Fatty acid: $1, \mathrm{i}-\mathrm{C}_{14: 0} ; 2, \mathrm{C}_{14: 0} ; 3, \mathrm{i}-\mathrm{C}_{15: 0} ; 4$, ai- $\mathrm{C}_{15: 0} ; 5, \mathrm{C}_{15: 0} ; 6, \mathrm{i}-\mathrm{C}_{16: 0} ; 7, \mathrm{i}-\mathrm{C}_{16: 1} ; 8, \mathrm{C}_{16: 0} ; 9, \mathrm{C}_{16: 1} ; 10, \mathrm{i}-\mathrm{C}_{17: 0} ; 11$, ai-C $\mathrm{C}_{17: 0} ; 12$, ai- $\mathrm{C}_{17: 1} ; 13, \mathrm{C}_{17: 0} ; 14, \mathrm{C}_{17: 1} ; 15, \mathrm{i}-\mathrm{C}_{18: 0} ; 16, \mathrm{C}_{18: 0} ; 17, \mathrm{C}_{18: 1} ; 18$, TBSA (10-methyl octadecanoic acid). i- $\mathrm{C}_{15: 1}, \mathrm{C}_{15: 1}, \mathrm{i}^{-\mathrm{C}_{17: 1}}$ and $\mathrm{C}_{18: 2}$ were not observed. Values less than $1 \%$ are not shown; $\mathrm{i}$, iso; ai, anteiso.

\begin{tabular}{|c|c|c|c|c|c|c|c|c|c|c|c|c|c|c|c|c|c|c|}
\hline \multirow[t]{2}{*}{ Taxon } & \multicolumn{18}{|c|}{ Fatty acid composition (\%)* } \\
\hline & 1 & 2 & 3 & 4 & 5 & 6 & 7 & 8 & 9 & 10 & 11 & 12 & 13 & 14 & 15 & 16 & 17 & 18 \\
\hline $\mathrm{BC} 361^{\mathrm{T}} \uparrow$ & & $3 \cdot 4$ & & & & & & $41 \cdot 4$ & $14 \cdot 9$ & & & & & & & $2 \cdot 4$ & $33 \cdot 7$ & $2 \cdot 8$ \\
\hline$N$. jensenii & $1 \cdot 7$ & & $16 \cdot 7$ & & $1 \cdot 3$ & $28 \cdot 6$ & $2 \cdot 8$ & $4 \cdot 3$ & $2 \cdot 3$ & $9 \cdot 6$ & $1 \cdot 0$ & & 3.9 & $6 \cdot 5$ & 1.5 & $1 \cdot 6$ & $10 \cdot 3$ & $2 \cdot 4$ \\
\hline N. albus & $2 \cdot 3$ & & 1.7 & & 1.5 & $70 \cdot 8$ & & $3 \cdot 0$ & 1.9 & & $2 \cdot 1$ & & $2 \cdot 1$ & $6 \cdot 0$ & $2 \cdot 1$ & & $2 \cdot 6$ & 1.9 \\
\hline N. simplex & $4 \cdot 6$ & & $2 \cdot 6$ & & & $41 \cdot 8$ & $1 \cdot 1$ & $3 \cdot 8$ & $5 \cdot 0$ & 1.9 & & & & $5 \cdot 2$ & & & $13 \cdot 1$ & $5 \cdot 2$ \\
\hline N. plantarum & & & $3 \cdot 4$ & & $1 \cdot 0$ & $26 \cdot 0$ & & $2 \cdot 9$ & $1 \cdot 0$ & $5 \cdot 4$ & $16 \cdot 8$ & & $6 \cdot 1$ & $4 \cdot 0$ & 1.8 & & $15 \cdot 7$ & $1 \cdot 9$ \\
\hline N. pyridinolyticus & & & $5 \cdot 1$ & $1 \cdot 4$ & & $47 \cdot 3$ & $4 \cdot 2$ & $1 \cdot 2$ & & 1.7 & $14 \cdot 2$ & $2 \cdot 1$ & $1 \cdot 2$ & $1 \cdot 7$ & & $1 \cdot 0$ & $2 \cdot 0$ & $3 \cdot 4$ \\
\hline A. erythreum $\S$ & & $3 \cdot 1$ & & & $3 \cdot 1$ & & & $47 \cdot 0$ & $5 \cdot 2$ & & & & $2 \cdot 4$ & $2 \cdot 1$ & & $3 \cdot 0$ & $18 \cdot 9$ & $5 \cdot 0$ \\
\hline A. fastidiosum $\uparrow$ & & $1 \cdot 1$ & & & $1 \cdot 4$ & & & $20 \cdot 6$ & $5 \cdot 4$ & & & & & & & $2 \cdot 7$ & $20 \cdot 2$ & $15 \cdot 8$ \\
\hline
\end{tabular}

* Data (except for strain BC $361^{\mathrm{T}}$ and $N$. pyridinolyticus) from Schumann et al. (1997).

$\dagger$ Strain contained additionally 1.4\% 2-hydroxy hexadecanoic acid.

$\$$ Data from Yoon et al. (1997). Strain contained additionally 5.5\% 10-methyl heptadecanoic acid and 5.0\% 10-methyl hexadecanoic acid.

$\S$ Strain contained additionally 4.6\% 2-hydroxy hexadecanoic acid.

ๆ Strain contained additionally $20.3 \%$ 2-hydroxy hexadecanoic acid.

Table 3. Differential characteristics of strain $\mathrm{BC} 361^{\top}$ and members of the family Nocardioidaceae

Abbreviations: DPG, diphosphatidylglycerol; PG, phosphatidylglycerol; PG-OH, PG containing 2-hydroxy fatty acids; PI, phosphatidylinositol; PE, phosphatidylethanolamine; PL, unknown phospholipid(s); menaquinones e.g. MK-9 $\left(\mathrm{H}_{4}\right)$, menaquinone with two of nine isoprene units hydrogenated.

\begin{tabular}{|c|c|c|c|c|c|}
\hline Taxon & $\begin{array}{c}\text { Cell } \\
\text { morphology }\end{array}$ & $\begin{array}{c}\text { Major } \\
\text { menaquinone }\end{array}$ & Polar lipids & $\begin{array}{l}\mathrm{G}+\mathrm{C} \\
(\mathbf{m o l} \%)\end{array}$ & Reference \\
\hline BC $361^{\mathrm{T}}$ & Cocci in packets & MK- $8\left(\mathrm{H}_{4}\right)$ & PI, PG, DPG, PL & 72 & \\
\hline Aeromicrobium & Rods & MK-9 $\left(\mathrm{H}_{4}\right)$ & PE, $\mathrm{PG}$ & $71-73$ & $\begin{array}{l}\text { Miller et al. (1991); Tamura \& Yokota } \\
\text { (1994) }\end{array}$ \\
\hline N. albus & Hyphae & $\mathrm{MK}-8\left(\mathrm{H}_{4}\right)$ & $\begin{array}{l}\text { PG, DPG, PL, } \\
\text { PG-OH }\end{array}$ & $66 \cdot 5-68 \cdot 6$ & $\begin{array}{l}\text { Prauser (1986); Collins et al. (1989); } \\
\text { O'Donnell et al. (1982) }\end{array}$ \\
\hline N. simplex & Rods/cocci & $\mathrm{MK}-8\left(\mathrm{H}_{4}\right)$ & $\begin{array}{l}\text { PG, DPG, PL, } \\
\text { PG-OH }\end{array}$ & $71 \cdot 7$ & $\begin{array}{l}\text { Collins et al. (1989); O’Donnell et al. } \\
\text { (1982) }\end{array}$ \\
\hline
\end{tabular}

family-specific 16S rDNA signature nucleotides, strain BC $361^{\mathrm{T}}$ exhibits several secondary-structure-forming nucleotides that are not present in the 16S rDNA sequences of any other member of the family. These nucleotides are found at positions (numbered according to E. coli) 183-194 (G-C), 987-1218 (A-U), 1002-1138 (A-U), 1012-1017 (G-C) 1089-1216 (G-C), 1422-1478 (U-G) and 1423-1479 (U-A).

\section{DISCUSSION}

Rock and monument surfaces support a high variety of microflora that often have been only poorly studied. In the last few years, however, it has become evident that a great variety of Actinobacteria could be considered as the major colonizer of stone surfaces exposed to the outdoor environment. Among them, strains of Micrococcus, Geodermatophilus and Micromonospora (Urzì \& Realini, 1998) were very often isolated and representatives of novel taxa might be expected (unpublished data). Tests based upon morphological as well as biochemical and physiological characteristics turned out to be insufficient to identify all isolated strains at the genus level. In the case of strain $\mathrm{BC} 361^{\mathrm{T}}$, the first attempt carried out using classical identification methods misplaced it in the genus Micrococcus. Later on, LL-A ${ }_{2} \mathrm{pm}$ was found to be the characteristic diamino acid of the cell wall. This 
finding was in conflict with the affiliation of strain BC $361^{\mathrm{T}}$ to the genus Micrococcus or related genera (Stackebrandt et al., 1995) and initiated a study of chemotaxonomic characteristics and phylogenetic relatedness of the strain in question.

The combination of the chemotaxonomic characteristics, peptidoglycan structure, menaquinone profiles and fatty acid composition is very helpful to differentiate genera of the order Actinomycetales and especially to distinguish strains containing LL-A ${ }_{2} \mathrm{pm}$ in their cell wall (Schumann et al., 1997; Prauser et al., 1997). Strain BC $361^{\mathrm{T}}$ showed the peptidoglycan type A $3 \gamma$ with a single glycine residue as interpeptide bridge, MK- $8\left(\mathrm{H}_{4}\right)$ as predominant menaquinone and only straight-chain saturated and unsaturated fatty acids and TBSA (Tables 2 and 3). Peptidoglycan structure and the major menaquinone of strain $\mathrm{BC} 361^{\mathrm{T}}$ are consistent with the genus description of the genus Nocardioides, but the complete absence of iso- and anteiso-branched chain fatty acids and the presence of phosphatidylinositol clearly separates strain BC $361^{\mathrm{T}}$ from representatives of this genus. Exclusively straight-chain saturated and unsaturated fatty acids and TBSA in combination with peptidoglycan type A $3 \gamma$ with a single glycine residue as interpeptide bridge are in agreement with the genus description of Aeromicrobium, but strain $\mathrm{BC} 361^{\mathrm{T}}$ differs from all strains of this genus in containing MK-8 $\left(\mathrm{H}_{4}\right)$ as major menaquinone and by the absence of phosphatidylethanolamine. In regard to its chemotaxonomic characteristics, strain $\mathrm{BC} 361^{\mathrm{T}}$ seemed to occupy an 'intermediate position' between the genera Nocardioides and Aeromicrobium.

The phylogenetic analysis based on $16 \mathrm{~S}$ rDNA sequence comparison placed strain $\mathrm{BC} 361^{\mathrm{T}}$ between the genera Nocardioides and Aeromicrobium and revealed $N$. jensenii ( $96 \cdot 4 \%$ similarity) as its closest phylogenetic neighbour (Fig. 1). As published by Yoon et al. (1998a, b), $N$. jensenii shows the highest $16 \mathrm{~S}$ rDNA similarity $(95.0 \%)$ and the highest $16 \mathrm{~S}-23 \mathrm{~S}$ internally transcribed spacer sequence similarity $(73 \cdot 1 \%)$ of all validly published Nocardioides species to Aeromicrobium erythreum, the type species of the genus Aeromicrobium. Despite its phylogenetic proximity to the genus Aeromicrobium, the fatty acid profile and all other chemotaxonomic features characterize $N$. jensenii as a true member of the genus Nocardioides (Schumann et al., 1997; Suzuki \& Komagata, 1983; Collins et al., 1989). Strain BC $361^{\mathrm{T}}$ differs from its closest phylogenetic neighbour $N$. jensenii not only by chemotaxonomic characteristics but also by sequences of the PCR primer designed for rapid identification of $N$. jensenii by multiplex PCR (Park et al., 1998) and of $16 \mathrm{~S}$ rDNA of strain BC $361^{\mathrm{T}}$. The nucleotide pair G-G at position 445 and 446 in $N$. jensenii is replaced by the pair C-A in the sequence of strain $\mathrm{BC} 361^{\mathrm{T}}$. In addition, strain $\mathrm{BC} 361^{\mathrm{T}}$ exhibits several secondary-structureforming nucleotides that are not present in the $16 \mathrm{~S}$ rDNA sequences of any other member of the family. Thus, strain BC $361^{\mathrm{T}}$ possesses a unique combination of chemotaxonomic and phylogenetic characteristics. Since it could readily be distinguished from representatives of all phylogenetically related genera, it is concluded that the organism should be assigned to a new genus and species for which the name Marmoricola aurantiacus is proposed.

\section{Description of Marmoricola gen. nov.}

Marmoricola. (Mar.mo.ri'co.la. L. neutr. n. marmor marble; L. masc. suffix - cola inhabitant of; Marmoricola inhabitant of marble).

Cells are Gram-positive, not acid-fast, spherical, occurring singly, in pairs, tetrads and small clusters. Non-motile and non-sporulating. No rod/coccus life cycle. Colonies are circular, convex, entire, orangepigmented, shiny and smooth. They can become rough and shaped like craters in old cultures. Aerobic. Catalase-positive, oxidase-negative. The cell wall peptidoglycan contains LL-A ${ }_{2} \mathrm{pm}$ as characteristic diamino acid and a single glycine residue as interpeptide bridge (type A $3 \gamma$ ). The acyl type is acetyl. Phospholipids are phosphatidylinositol, phosphatidylglycerol and diphosphatidylglycerol. Mycolic acids are absent. The cellular fatty acid profile consists of straight-chain saturated and monounsaturated components and TBSA as the only branched chain fatty acid. The major menaquinone is MK- $8\left(\mathrm{H}_{4}\right)$. The DNA $\mathrm{G}+\mathrm{C}$ content is $72 \mathrm{~mol} \%$. Phylogenetically, this genus is a member of the family Nocardioidaceae (Stackebrandt et al., 1997). The type species is Marmoricola aurantiacus.

\section{Description of Marmoricola aurantiacus sp. nov.}

Marmoricola aurantiacus (au.ran.ti'a.cus. M.L. adj. aurantiacus orange-coloured).

Cells are spherical occurring singly, in pairs, tetrads and small clusters $(0.5-0.7 \mu \mathrm{m}$ in diameter). Nonmotile and non-sporulating. No rod/coccus life cycle. Colonies are circular, convex, entire, orange-pigmented, shiny and smooth (2-5 $\mathrm{mm}$ in diameter). They can become rough and shaped like craters in old cultures. Aerobic. Catalase-positive, oxidase-negative. Nitrate is not reduced to nitrite. No acid production is observed from D-ribose, L-arabinose, D-xylose, Lrhamnose, D-glucose, D-mannose, D-galactose, maltose, lactose, D-cellobiose, D-trehalose, D-raffinose, glycerol, D-mannitol or myo-inositol. Casein and gelatin are not hydrolysed. Xanthine and tyrosine are not decomposed; hypoxanthine is decomposed. Aesculin is hydrolysed, Tween 80 is only weakly hydrolysed. DNA is not hydrolysed. The strain does not grow in the following media: CZ, YMS-Glc, YCSGlc, YG-Glyc, Y-Glyc, agar- $\mathrm{H}_{2} \mathrm{O}$ and M53. Growth occurs in Luedemann, PDA and BHIA media. The cell wall peptidoglycan contains LL- $\mathrm{A}_{2}$ pm as characteristic diamino acid and a single glycine residue as inter-

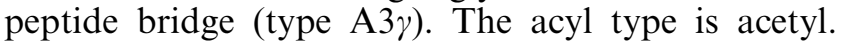
Phospholipids are phosphatidylinositol, phosphatidyl- 
glycerol and diphosphatidylglycerol. Mycolic acids are absent. The cellular fatty acid profile consists of straight-chain saturated and monounsaturated components and TBSA as the only branched chain fatty acid. The major menaquinone is MK- $8\left(\mathrm{H}_{4}\right)$. The DNA $\mathrm{G}+\mathrm{C}$ content is $72 \mathrm{~mol} \%$. Phylogenetically, it is a member of the family Nocardioidaceae. The only known isolation site is a Carrara marble statue (Wagmüller's monument) located in the Nordfriedhof Cemetery in Munich, Germany. The type strain is strain BC $361^{\mathrm{T}}$ (bacterial collection of the Institute of Microbiology, Messina). It has been deposited in the DSMZ - German Collection of Microorganisms and Cell Cultures $\mathrm{GmbH}$ as strain DSM $12652^{\mathrm{T}}$.

\section{ACKNOWLEDGEMENTS}

This study was supported by the financial contribution of CNR (PF 97.00720. PF36) and EC (project ENV4-CT980707). P.S. acknowledges the grant received by EC in the frame of project no. ENV4-CT98-0704. The authors would like to thank Dr Helmut Prauser for the stimulating discussion and Professor Hans G. Trüper for his valuable help in assigning the generic and specific name to the strain BC $361^{\mathrm{T}}$.

\section{REFERENCES}

Bunt, J. S. \& Rovira, A. D. (1955). Microbiological studies of some subantarctic soils. J Soil Sci 6, 119-128.

Busse, H.-J. \& Schumann, P. (1999). Polyamine profiles within genera of the class Actinobacteria with LL-diaminopimelic acid in the peptidoglycan. Int $J$ Syst Bacteriol 49, 179-184.

Collins, M. D. \& Jones, D. (1980). Lipids in the classification and identification of coryneform bacteria containing peptidoglycans based on 2,4-diaminobutyric acid. J Appl Bacteriol 48, 459-470.

Collins, M. D. \& Stackebrandt, E. (1989). Molecular taxonomic studies on some LL-diaminopimelic acid-containing coryneforms from herbage: description of Nocardioides fastidiosa sp. nov. FEMS Microbiol Lett 57, 289-294.

Collins, M. D., Pirouz, T., Goodfellow, M. \& Minnikin, D. E. (1977). Distribution of menaquinones in actinomycetes and corynebacteria. J Gen Microbiol 100, 221-230.

Collins, M. D., Dorsch, M. \& Stackebrandt, E. (1989). Transfer of Pimelobacter tumescens to Terrabacter gen. nov. as Terrabacter tumescens comb. nov. and of Pimelobacter jensenii to Nocardioides as Nocardioides jensenii comb. nov. Int $J$ Syst Bacteriol 39, 1-6.

Collins, M. D., Cockcroft, S. \& Wallbanks, S. (1994). Phylogenetic analysis of a new LL-diaminopimelic acid-containing coryneform bacterium from herbage, Nocardioides plantarum $\mathrm{sp}$. nov. Int J Syst Bacteriol 44, 523-526.

DeSoete, G. (1983). A least squares algorithm for fitting additive trees to proximity data. Psychometrika 48, 621-626.

Felsenstein, J. (1993). PHYLIP (phylogenetic inference package) version 3.5.1. Department of Genetics, University of Washington, Seattle, WA, USA.

Gordon, R. E., Barnett, D. A., Handerhan, J. E. \& Pang, C. H. N. (1974). Nocardia coeliaca, Nocardia autotrophica, and the nocardin strain. Int J Syst Bacteriol 24, 54-63.

Groth, I., Schumann, P., Weiss, N., Martin, K. \& Rainey, F. A. (1996). Agrococcus jenensis gen. nov., sp. nov., a new genus of actinomycetes with diaminobutyric acid in the cell wall. Int $J$ Syst Bacteriol 46, 234-239.

Groth, I., Schumann, P., Rainey, F. A., Martin, K., Schuetze, B. \& Augsten, K. (1997). Bogoriella caseilytica gen. nov., sp. nov., a new alkaliphilic actinomycete from a soda lake in Africa. Int $J$ Syst Bacteriol 47, 788-794.

Jukes, T. H. \& Cantor, C. R. (1969). Evolution of protein molecules. In Mammalian Protein Metabolism, vol. 3, pp. 21-132. Edited by H. N. Munro. New York: Academic Press. Lanyi, B. (1987). Classical and rapid identification methods for medically important bacteria. Methods Microbiol 19, 1-67.

Luedemann, G. M. (1968). Geodermatophilus, a new genus of the Dermatophilaceae (Actinomycetales). J Bacteriol 96, 1848-1858.

Luedemann, G. M. \& Fonseca, A. F. (1989). Genus Geodermatophilus Luedemann 1968, 1857 $7^{\mathrm{AL}}$. In Bergey's Manual of Systematic Bacteriology, vol. 4, pp. 2406-2409. Edited by S. T. Williams, M. E. Sharpe \& J. G. Holt. Baltimore: Williams \& Wilkins.

MacKenzie, S. L. (1987). Gas chromatographic analysis of amino acids as the $N$-heptafluorobutyryl isobutyl esters. $J$ Assoc Off Anal Chem 70, 151-160.

Maidak, B. L., Larsen, N., McCaughey, M. J., Overbeek, R., Olsen, G. J., Fogel, K., Blandy, J. \& Woese, C. R. (1994). The Ribosomal Database Project. Nucleic Acids Res 22, 3485-3487

Miller, E. S., Woese, C. R. \& Brenner, S. (1991). Description of the erythromycin-producing bacterium Arthrobacter sp. strain NRRL B-3381 as Aeromicrobium erythreum gen. nov., sp. nov. Int $J$ Syst Bacteriol 41, 363-368.

Minnikin, D. E., Alshamaony, L. \& Goodfellow, M. (1975). Differentiation of Mycobacterium, Nocardia, and related taxa by thin-layer chromatographic analysis of whole-organism methanolysates. J Gen Microbiol 88, 200-204.

Minnikin, D. E., Collins, M. D. \& Goodfellow, M. (1979). Fatty acid and polar lipid composition in the classification of Cellulomonas, Oerskovia and related taxa. J Appl Bacteriol 47, 87-95.

O'Donnell, A. G., Goodfellow, M. \& Minnikin, D. E. (1982). Lipids in the classification of Nocardioides: reclassification of Arthrobacter simplex (Jensen) Lochhead in the genus $\mathrm{No}$ cardioides (Prauser) emend. O'Donnell et al. as Nocardioides simplex comb. nov. Arch Microbiol 133, 323-329.

Park, Y.-H., Yoon, J.-H. \& Lee, S. T. (1998). Application of multiplex PCR using species-specific primers within the $16 \mathrm{~S}$ rRNA gene for rapid identification of Nocardioides strains. Int J Syst Bacteriol 48, 895-900.

Prauser, H. (1976). Nocardioides, a new genus of the order Actinomycetales. Int J Syst Bacteriol 26, 58-65.

Prauser, H. (1984). Nocardioides luteus sp. nov. Z Allg Mikrobiol 24, 647-648.

Prauser, H., Schumann, P., Rainey, F. A., Kroppenstedt, R. M. \& Stackebrandt, E. (1997). Terracoccus luteus gen. nov., sp. nov., an LL-diaminopimelic acid-containing coccoid actinomycete from soil. Int J Syst Bacteriol 47, 1218-1224.

Rainey, F. A., Ward-Rainey, N., Kroppenstedt, R. M. \& Stackebrandt, E. (1996). The genus Nocardiopsis represents a phylogenetically coherent taxon and a distinct actinomycete lineage: proposal of Nocardiopsaceae fam. nov. Int $J$ Syst Bacteriol 46, 1088-1092.

Schleifer, K. H. (1985). Analysis of the chemical composition and primary structure of murein. In Methods in Microbiology, vol. 18, pp. 123-156. Edited by G. Gottschalk. London: Academic Press. 
Schleifer, K. H. \& Kandler, O. (1972). Peptidoglycan types of bacterial cell walls and their taxonomic implications. Bacteriol Rev 36, 407-477.

Schumann, P., Prauser, H., Rainey, F. A., Stackebrandt, E. \& Hirsch, P. (1997). Friedmanniella antarctica gen. nov., sp. nov., an LL-diaminopimelic acid-containing actinomycete from Antarctic sandstone. Int J Syst Bacteriol 47, 278-283.

Stackebrandt, E., Koch, C., Gvozdiak, O. \& Schumann, P. (1995). Taxonomic dissection of the genus Micrococcus: Kocuria gen. nov., Nesterenkonia gen. nov., Kytococcus gen. nov., Dermacoccus gen. nov., and Micrococcus Cohn 1872 gen. emend. Int J Syst Bacteriol 45, 682-692.

Stackebrandt, E., Rainey, F. A. \& Ward-Rainey, N. (1997). Proposal for a new hierarchic classification system, Actinobacteria classis nov. Int J Syst Bacteriol 47, 479-491.

Stead, D. E., Sellwood, J. E., Wilson, J. \& Viney, I. (1992). Evaluation of a commercial microbial identification system based on fatty acid profiles for rapid, accurate identification of plant-pathogenic bacteria. J Appl Bacteriol 72, 315-321.

Suzuki, K.-I. \& Komagata, K. (1983). Pimelobacter gen. nov., a new genus of coryneform bacteria with LL-diaminopimelic acid in the cell wall. J Gen Appl Microbiol 29, 59-71.
Tamura, T. \& Yokota, A. (1994). Transfer of Nocardioides fastidiosa Collins and Stackebrandt 1989 to the genus Aeromicrobium as Aeromicrobium fastidiosum comb. nov. Int $J$ Syst Bacteriol 44, 608-611.

Uchida, K. \& Aida, K. (1984). An improved method for the glycolate test for simple identification of the acyl type of bacterial cell walls. J Gen Appl Microbiol 30, 131-134.

Urzì, C. \& Realini, M. (1998). Colour changes of Noto's Calcareous Sandstone as related with its colonization by microorganisms. Int Biodeterior \& Biodegrad 42, 45-54.

Yoon, J.-H., Rhee, S.-K., Lee, J.-S., Park, Y.-H. \& Lee, S. T. (1997). Nocardioides pyridinolyticus sp. nov., a pyridine-degrading bacterium isolated from the oxic zone of an oil shale column. Int J Syst Bacteriol 47, 933-938.

Yoon, J.-H., Lee, S. T. \& Park, Y.-H. (1998a). Inter- and intraspecific phylogenetic analysis of the genus Nocardioides and related taxa based on $16 \mathrm{~S}$ rDNA sequences. Int J Syst Bacteriol 48, 187-194.

Yoon, J.-H., Lee, S. T. \& Park, Y.-H. (1998b). Genetic analyses of the genus Nocardioides and related taxa based on $16 \mathrm{~S}-23 \mathrm{~S}$ rDNA internally transcribed spacer sequences. Int $J$ Syst Bacteriol 48, 641-650. 